\title{
Effect of $0.15 \%$ sodium hialuronate and $0.5 \%$ carboxymethylcellulose on tear film breakup time in healthy dogs and in dogs with keratoconjunctivitis sicca
}

\author{
[Efeito do hialuronato de sódio a 0,15\% e da carboximetilcelulose sódica a 0,5\% no tempo de ruptura \\ do filme lacrimal de cães saudáveis e com ceratoconjuntivite seca] \\ G.M. Madruga, A.P. Ribeiro*, T.B.S. Magalhães, L.A.S. Rondelli, F.H. Furlan \\ Universidade Federal do Mato Grosso - Cuiabá, MT
}

\begin{abstract}
This study aimed to evaluate the effect of the $0.15 \%$ sodium hyaluronate (SH) and of $0.5 \%$ carboxymethylcellulose (CMC) on tear film breakup time (TFBUT) in 10 healthy dogs and in 32 eyes of dogs with keratoconjunctivis sicca (KCS). In addition, the goblet cell density (GCD) of this population was quantified. TFBUT was assessed at baseline and at different time points following the instillation of SH and CMC. KCS was graded as mild, moderate, and severe. GCD were quantified from conjunctival biopsies. The number of GCD differed significantly between patients with mild and moderate KCS $(\mathrm{P}<0.01)$. TFBUT of healthy dogs increased only for 1 minute after treatment with $\mathrm{SH}(\mathrm{P}<0.01)$. Regarding baseline and treatments, SH significantly increased TFBUT for up to 30 minutes on the ocular surface, in comparison to CMC, in all categories of KCS $(\mathrm{P}<0.01)$. TFBUT and GCD correlated positively when the healthy and diseased eyes were grouped $(\mathrm{r}=0.41, \mathrm{P}=0.006)$. It can be concluded that in dogs with $\mathrm{KCS}$, SH lasts longer periods on the ocular surface than CMC, but such agents does not increase TFBUT in healthy dogs. Additionally, tear film stability tends to reduce in a linear fashion from the mild to severe form of KCS.
\end{abstract}

Keywords: goblet cells, tear stability, lacrimomimetics, instillations

\section{RESUMO}

Objetivou-se avaliar os efeitos do hialuronato de sódio a 0,15\% (HS) e da carboximetilcelulose a 0,5\% (CMC) no teste de ruptura do filme lacrimal (TRFL) em 10 cães saudáveis e em 32 olhos de cães com ceratoconjuntivite seca (CCS). Ademais, quantificou-se a densidade de células caliciformes (DCC) deles. Mensurou-se o TRFL em momentos distintos antes e após a instilação do HS e da CMC. Graduou-se a CCS em leve, moderada e severa. Quantificou-se a DCC a partir de biópsias conjuntivais. A DCC diferiu apenas entre pacientes com CCS leve e severa $(P<0,01)$. Em cães saudáveis, o TRFL se elevou apenas após um minuto do tratamento com HS $(P<0,01)$. Relativamente ao periodo basal e entre os tratamentos, o HS elevou o TRFL de forma mais eficaz e permaneceu por até 30 minutos na superfície ocular, comparativamente à CMC, em todas as categorias de CCS $(P<0,01)$. Ao se agruparem os olhos saudáveis e os com CCS, o TRFL se correlacionou com a DCC $(\mathrm{r}=0.41, \mathrm{P}=0.006)$. Conclui-se que o HS permanece por maior tempo na superficie ocular que a CMC em cães com CCS, mas que tais substâncias não elevam o TRFL em cães saudáveis. Ademais, a estabilidade do filme lacrimal tende a se reduzir de modo linear da forma leve até à severa da CCS.

Palavras-chave: células caliciformes, estabilidade lacrimal, lacrimomiméticos, instilações

\section{INTRODUCTION}

In dogs, tear film abnormalities most commonly arose from the decrease in its aqueous component and are known as keratoconjunctivitis sicca (KCS). In this species, KCS usually results from idiopathic immunemediated $\mathrm{T}$ and $\mathrm{B}$-cell inflammation, which lead to destruction of the lacrimal glands (Giuliano,
2013). Other causes include drug toxicity (sulfonamides, etodolac, and atropine), anesthetic agents, neurogenic, iatrogenic (excision of nictitans gland), endocrine disorders, irradiation, infectious lacrimal adenitis (distemper and leishmaniasis), chronic blepharoconjunctivitis, and congenital hypoplasia (Giuliano, 2013; Ribeiro, 2015). In dogs, this can also occur as a qualitative

Recebido em 7 de fevereiro de 2017

Aceito em 10 de julho de 2017

*Autor para correspondência (corresponding author)

E-mail: alexandre.aleribs@gmail.com 
abnormality, due to deficiency in the lipid (produced by tarsal glands) or mucin (produced by conjunctival goblet cells) layers, resulting in tear film evaporation and instability, respectively (Giuliano, 2013; Ribeiro, 2015). Schirmer tear test (STT) is the main tool used to diagnose KCS in dogs (Giuliano, 2013; Ribeiro, 2015). In addition, grading the KCS in accordance with STT results as mild, moderate and severe may dictate the prognosis of this disease (Giuliano, 2013; Ribeiro, 2015). Nonetheless, patients with qualitative abnormalities may present STT within the reference ranges and decreased tear film breakup time (TFBUT). Both tear deficiencies cause conjunctivitis, ocular discomfort, ulcerative, and non-ulcerative keratites that may lead to blindness (Giuliano, 2013; Ribeiro, 2015). For the management of these diseases, lacrimomimetics are recommended until lacrimostimulants, such as cyclosporine and tacrolimus are able to rise STT values above 15mm/min. (Giuliano, 2013; Ribeiro, 2015).

Lacrimomimetics are tear film substitutes that attempt to supplement all parts of the tear film, increasing the volume and stability of this layer, and protecting the ocular surface against desiccation (Araujo and Galera, 2016). Sodium hyaluronate $(\mathrm{SH})$ is a glycosaminoglycan, present in natural tears, with excellent viscoelastic, lubricating and water retention properties (Araujo and Galera, 2016). Carboxymethylcellulose (CMC) is the most commonly used agent in commercial formulations, as it has desirable mucoadhesive and viscoelastic properties and a high retention time on the ocular surface (Araujo and Galera, 2016).

The retention time of the $\mathrm{SH}$ and CMC on the ocular surface have been determined in humans with KCS, as well as in rabbits and rats with experimentally-induced KCS (Mengher et al., 1986; Hamano et al., 1996; Johnson et al., 2006; Lee et al., 2011; Zheng et al., 2014; Yao et al., 2015). Studies carried out in dogs only have shown that $\mathrm{SH}$ and other lacrimomimetics improve the clinical signs related to the ocular surface desiccation (Williams and Mann 2013, Hasegawa et al., 2016). Although the literature recommends that lacrimomimetics should be instilled more than 6 times a day, studies with regard to retention time of such agents on the ocular surface of dogs have not been published (Williams and Mann 2013; Ribeiro, 2015).

Thus, this study aimed to determine and compare the effects of $0.15 \% \mathrm{SH}$ and $0.5 \% \mathrm{CMC}$ on the stability of the tear film, by means of TFBUT assessment in healthy dogs and in those with KCS with different grades. Considering that the conjunctival goblet cell density (GCD) may help to diagnose KCS and, so far, only one study evaluated such parameter in dogs with qualitative KCS (Cullen et al., 2005), we also considerate to assess possible correlations between the GCD and TFBUT in the population of dogs studied.

\section{MATHERIALS AND METHODS}

The experimental and clinical study were approved by the institutional Committee for Ethics in the Use of Animals (protocols 23108.118102/2015-51 and 23108.188779/201659). Ten healthy ( 8 female and two male) dogs, of breeds poodle $(n=4)$ and yorkshires $(n=6)$, with average age and weight of 3 years and $2.5 \mathrm{~kg}$, respectively, were used. For the inclusion criteria, healthy animals were selected based on a full clinical and ophthalmic examination. In addition, complete blood cell count, as well as alanine transaminase, creatinine, and urea were carried out. Selected dogs were kept in a room with 500 lux luminosity, 60 to $62 \%$ of relative humidity, 22 to $26{ }^{\circ} \mathrm{C}$ of temperature (Medidor Multifunção ITMP-600 ${ }^{\circledR}$, Instrutemp Instrumentos de Medição Ltda, Brasil), were exposed to 12 hours of light/dark cycle, fed with dog dry pellet twice daily, and provided with water ad libitum.

Patients admitted to the ophthalmology service of the Veterinary Teaching Hospital of the Federal University of Mato Grosso with STT values less than $15 \mathrm{~mm} /$ minutes, presenting at least one of the following clinical signs: ocular discharge, conjunctival hyperemia, and corneal abnormalities such as edema, neovascularizalion, and melanosis were diagnosed with KCS. The degree of KCS were graded in accordance with STT readings into three categories: mild (11$14 \mathrm{~mm} / \mathrm{min}$.), moderate $(6-10 \mathrm{~mm} / \mathrm{min}$.), and severe (0-5mm/min.) (Giuliano, 2013). Only dogs with the immune-mediated form of KCS were included in the study. 
Before the beginning of the experiment, healthy individuals were adapted for a period of 7 days to the procedures and examiners. The TFBUT was performed following the instillation of one drop of $0.1 \mathrm{~mL}$ of $1 \%$ sodium fluorescein (Fluoresceínasódica 1\%, Allergan ${ }^{\circledR}$, Inc., São Paulo) at the dorsal bulbar conjunctiva and the eyelid was held closed. After a manually controlled blink, the eyelids were gently held open in synchrony with the start of a chronometer and the dorsolateral corneal surface was observed with 16x magnification and cobalt blue filter of a slit-lamp biomicroscope (SL-14 ${ }^{\circledR}$, Kowa Company, Tokyo, Japan). The chronometer was stopped when the first sign of tear film breakup was seen, which was interpreted by the observation of one or more dark striae among the green fluorescence of the ocular surface. The TFBUT was performed in one eye at a time, and at the end of the procedure, the ocular surface was rinsed with saline.

After the acclimation period, TFBUT was performed as aforementioned before in order to obtain baseline values. Afterwards, TFBUT was assessed following 1, 5, and 10 minutes of the instillation of one drop of a preservative free $0.15 \%$ sodium hyaluronate $(\mathrm{SH})$ (Hyabak $0,15 \%{ }^{\circledR}$, Genon, São Paulo, Brasil) or $0.5 \%$ sodium carboxymethylcellulose (CMC) (Fresh Tears $0,5 \%{ }^{\circledR}$, Allergan, Inc., São Paulo). In all occasions, the evaluations were performed in a blind fashion in regard to treatments and time points. In addition, in order to avoid bias in regard to lacrimal stimulation, each measurement was performed with a washout period of 24 hours. During the acclimation period and the experimental phase, TFBUT was always assessed at 1 P.M.

The same methodology adopted to assess TFBUT in healthy dogs were used in the patients with KCS. Except that patients enrolled in this study were owned client dogs, allowed to participate in the experiment with the owner consent. In this population, the period of acclimation was of only two days. At day three, baseline TFBUT values were established. Afterwards, such parameter was assessed following 1, 5, 10, 30 and 60 minutes of the instillation of the same lacrimomimetics used in the healthy subjects. The same criteria with regard to intervals between evaluations, as well as the hour of the day established to perform the TFBUT in healthy dogs were adopted to the dogs with KCS.

At the end of the experimental phase, the ocular surface was rinsed with $0.5 \%$ povidone-iodine solution. Afterwards, one drop of $0.5 \%$ proxymetacaine (Anestalcon $®$ Alcon Laboratorios do Brasil Ltda., São Paulo, SP, Brasil) was instilled and following a two minute interval, a specimen of conjunctiva measuring $3.0 \mathrm{~mm}^{2}$ was collected from the ventral nasal fornice. Samples were routinely prepared and stained with Hematoxilin and Eosin and Acid Periodic Shiff. Under 40x of magnification the nuclei of 200 epithelial basal conjunctival cells were counted, and the amount of goblet cells present at those sites were quantified (GCD).

Shapiro-Wilk test was used to assess data normality. Comparisons of TFBUT values among periods were assessed by one way analysis of variance (1-ANOVA for repeated measures in healthy dogs and regular 1-ANOVA for dogs with KCS), followed by Tukey's test. TFBUT values between treatments were assessed by a 2-ANOVA, followed by Bonferroni's test. TFBUT and GCD values among healthy and diseased dogs were compared by Tukey's test. Possible correlations between the GCD and TFBUT values were assessed by Person's test. In all ocasions, differences were considered significant when $\mathrm{P}<0.05$. Data were present as mean \pm standard error of mean.

\section{RESULTS}

In healthy dogs, TFBUT assessed before and after treatments with $\mathrm{CMC}(\mathrm{P}=0.24)$ and $\mathrm{SH}$ $(\mathrm{P}=0.23)$ did not change significantly between the RE and LE. Average TFBUT assessed during baseline was $11.34 \pm 4.30$ seconds. Following 1 $(\mathrm{P}=0.46), 5(\mathrm{P}=0.95)$, and 10 minutes $(\mathrm{P}=0.99)$ of the instillation of CMC, TFBUT values did not change, in comparison to baseline values (Figure 1). After treatment with SH, TFBUT increased significantly only in the first minute of evaluation, when compared to baseline $(\mathrm{P}=0.003)$ and the other time points $(\mathrm{P}<0.01)$ (Figure 1). Comparisons between $\mathrm{CMC}$ and $\mathrm{SH}$ showed that the TFBUT increased significantly by 3.8 seconds $(\mathrm{P}<0.01)$ in $\mathrm{SH}$ treated-eyes, only in the first minute of evaluation (Figure 1). 


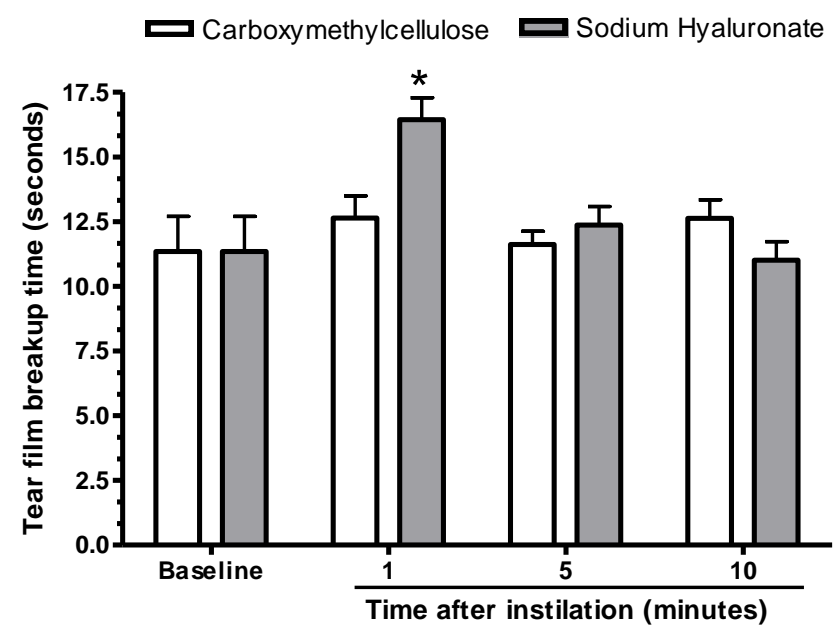

Figure 1. Values of tear film breakup time before (baseline) and following 1, 5, and 10 minutes of the instillation of $0.15 \%$ sodium hyaluronate and $0.5 \%$ carboxymethylcellulose in healthy dogs. ${ }^{*} \mathrm{P}<0.01$ in comparison to baseline and other time points of both agents.

Third two eyes of 24 patients ( 14 females and 10 males) with KCS met the inclusion criteria. Only one eye was affected in 16 dogs, and in 8 , both eyes were affected. Breeds enrolled were boxer (1 eye), shi tzu (4 eyes), pechinese (1 eye), poodle ( 8 eyes), french bulldog ( 1 eye), beagle ( 2 eyes), lhasa apso ( 3 eyes), and mixed breed (12 eyes). From the 32 eyes included, 10 were graded as mild, 10 as moderate, and 12 as severe $\mathrm{KCS}$.

TFBUT assessed during baseline in dogs with mild, moderate, and severe KCS, was, $8.04 \pm 0.38,5.59 \pm 0.31$, and $4.44 \pm 0.33$ seconds, respectively. When the 32 eyes with KCS were grouped, TFBUT was $5.93 \pm 0.33$ seconds. Average TFBUT of healthy dogs was significantly higher, when compared to all categories of dogs with $\mathrm{KCS} \quad(\mathrm{P}<0.01)$. In comparisons among categories, statistical significance was observed only between patients with mild and severe KCS $(\mathrm{P}<0.01)$.

In dogs with mild KCS, TFBUT values increased significantly only in the first minute of evaluation, following the instillation of CMC $(\mathrm{P}=0.0005)$ (Figure 2A). In patients with moderate and severe KCS, such parameter increased significantly only during the first 10 minutes of evaluation, following the instillation of $\mathrm{CMC}(\mathrm{P}<0.05)$ (Figure $2 \mathrm{~B}$ and $\mathrm{C})$; the same results were achieved after the eyes were treated with $\mathrm{SH}$, in patients with mild KCS $(\mathrm{P}<0.05)$
(Figure 2D). In the eyes graded as moderate and severe, such parameter increased significantly up to 30 minutes $(\mathrm{P}<0.05)$ (Figure $2 \mathrm{D}$ and $\mathrm{F})$.

Comparisons between treatments showed that $\mathrm{SH}$ was significantly more efficient in increasing the TFBUT values in almost all time points, and in all categories of KCS $(\mathrm{P}<0.01)$ (Figure 3A, B and $\mathrm{C}$ ). When the 32 eyes with $\mathrm{KCS}$ were grouped, higher values of TFBUT where seen for up to 30 minutes after treatment with $\mathrm{SH}$ $(\mathrm{P}<0.01)$ (Figure 3D).

In healthy dogs, average conjunctival GCD

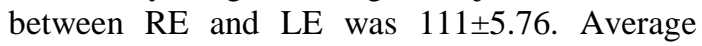
GCD in the eyes with mild, moderate, and severe KCS was $109.20 \pm 5.22,88.10 \pm 10.71$, and 47.25 \pm 11.11 , respectively (Figure 4A, B and C). GCD of healthy dogs was significantly higher, only when compared with the eyes graded with severe KCS $(\mathrm{P}<0.01)$ (Figure 4D). Among dogs with KCS, statistical significance was only observed between the eyes graded as mild and severe $(\mathrm{P}<0.01)$ (Figure 4D). In healthy dogs, TFBUT and GCD did not correlate $(r=0.11$, $\mathrm{P}=0.33$ ). Likewise, correlations between the same parameters were not found in the eyes with mild ( $\mathrm{r}=0.11, \mathrm{P}=074)$, moderate $(\mathrm{r}=-0.01$, $\mathrm{P}=0.95)$, and severe KCS $(\mathrm{r}=0.08, \mathrm{P}=0.79)$. However, when the eyes of healthy dogs were grouped with the eyes of all categories of KCS, positive correlation between TFBUT and GC was observed ( $r=0.41, \mathrm{P}=0.006)$ (Figure 5). 

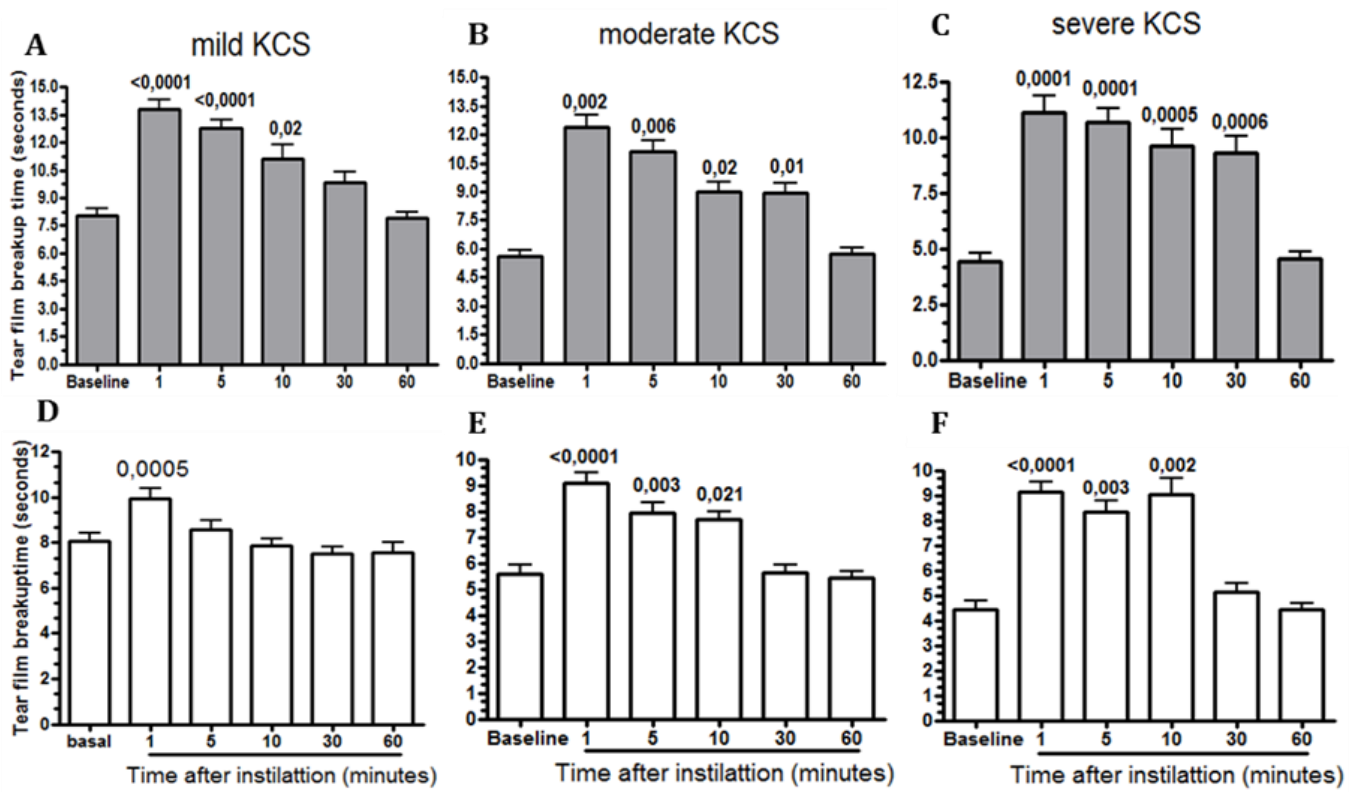

Figure 2. Values of tear film breakup time before (baseline) and following 1, 5, 10, 30, and 60 minutes of the instillation of $0.15 \%$ sodium hyaluronate (grey bars) and $0.5 \%$ carboxymethylcellulose (white bars) in dogs with mild (A and D), moderate (B and E), and severe (C and F) keratoconjunctivitis sicca (KCS). P values above bars differ significantly from baseline.
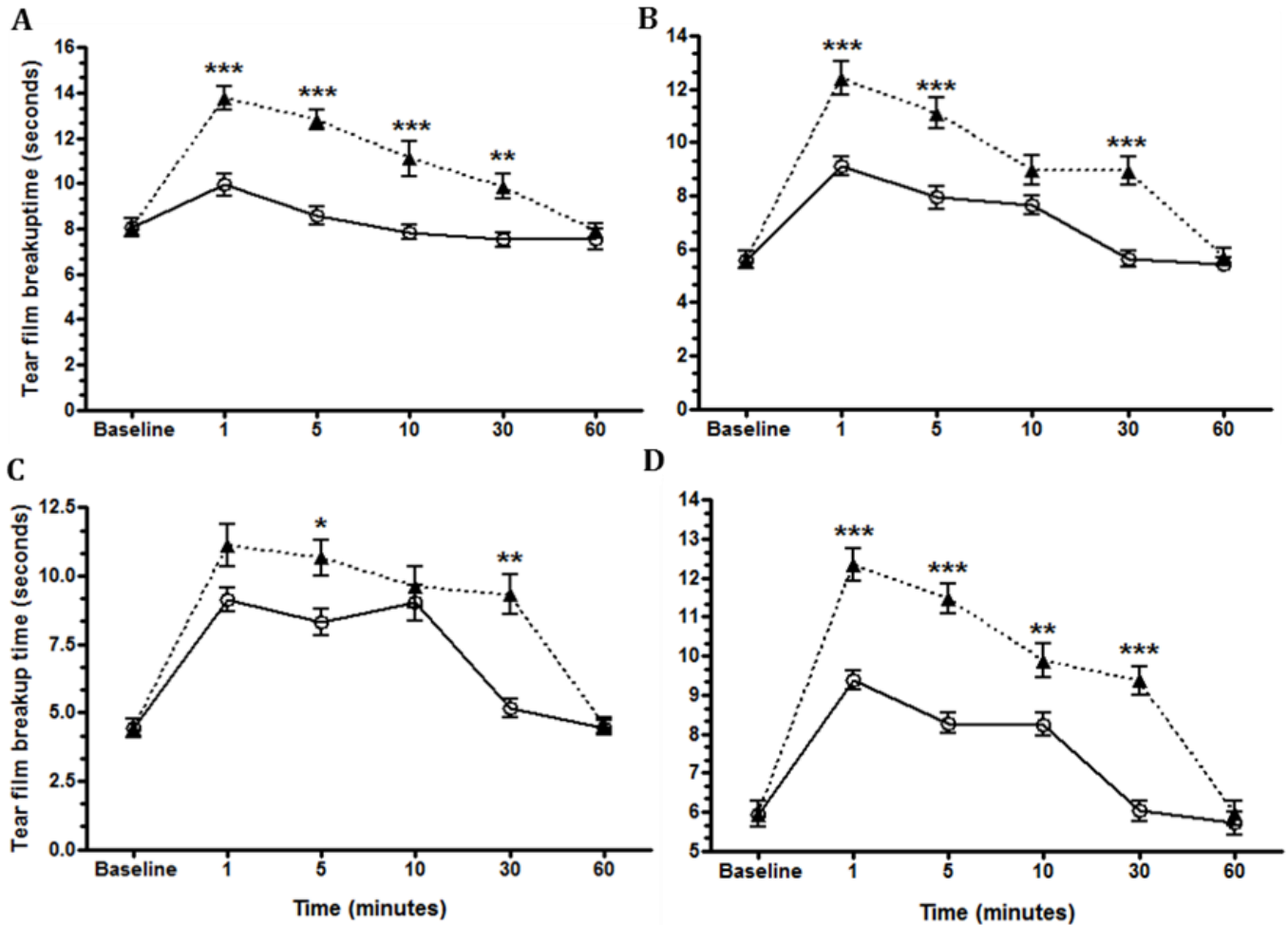

Figure 3. Values of tear film breakup time before (baseline) and following 1, 5, 10, 30, and 60 minutes of the instillation of $0.15 \%$ sodium hyaluronate (triangle) and $0.5 \%$ carboxymethylcellulose (circle) in dogs with mild (A), moderate (B), severe (C) keratoconjunctivitis sicca (KCS), and after grouping all categories $(\mathrm{D}) . *(\mathrm{P}<0.05), * *(\mathrm{P}<0.01)$, and $* * *(\mathrm{P}<0.0001)$ between treatments. 


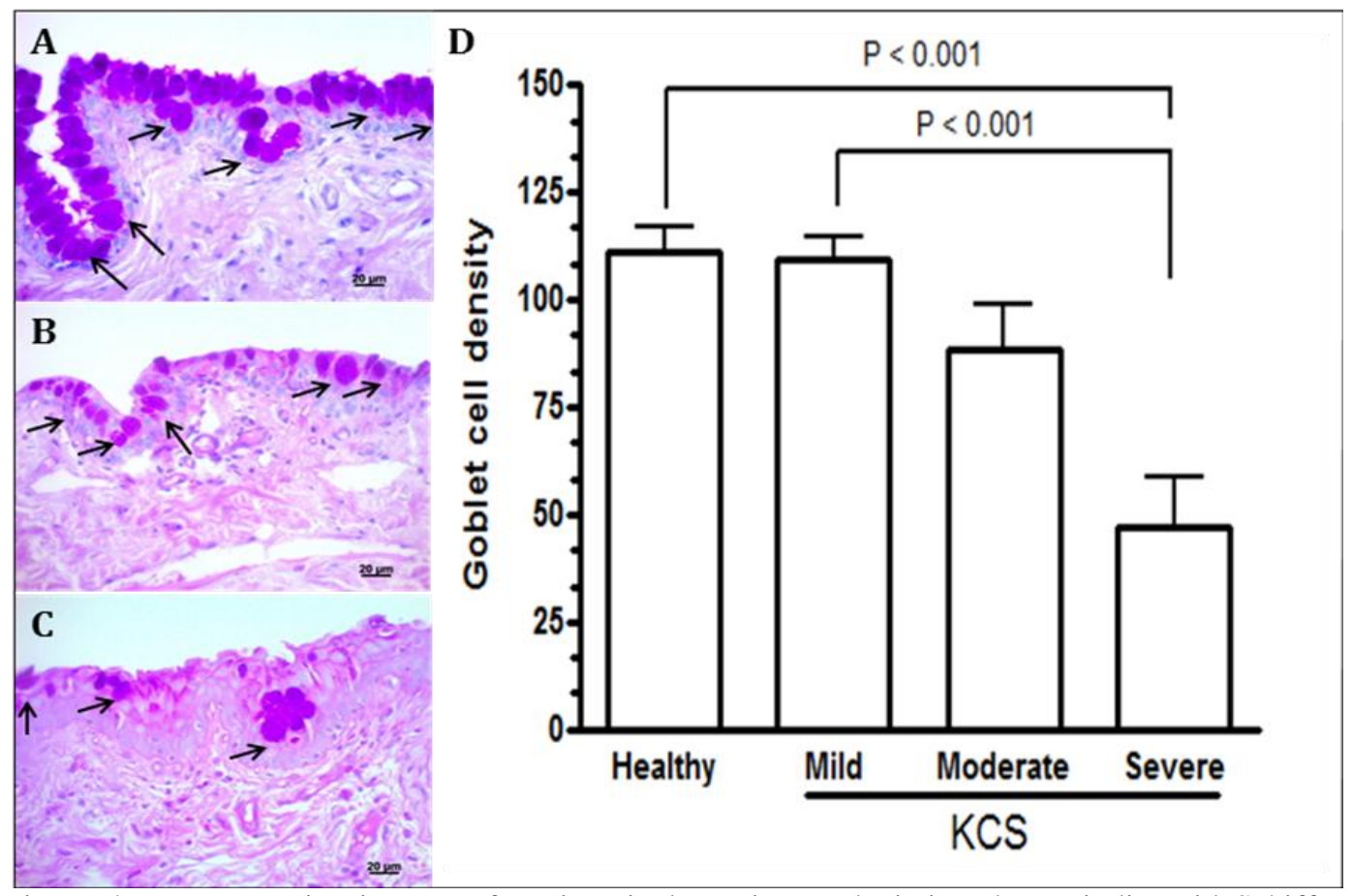

Figure 4. Representative images of conjunctival specimens depicting the periodic acid Schiff-positive goblet cells (GCD) (arrows) of dogs with mild (A), moderate (B), and severe (C) keratoconjunctivitis sicca $(\mathrm{KCS})$. Bars $=20 \mu \mathrm{m}$. In D, it can be observed values of GCD among healthy dogs and those with $\mathrm{KCS}$ at different grades.

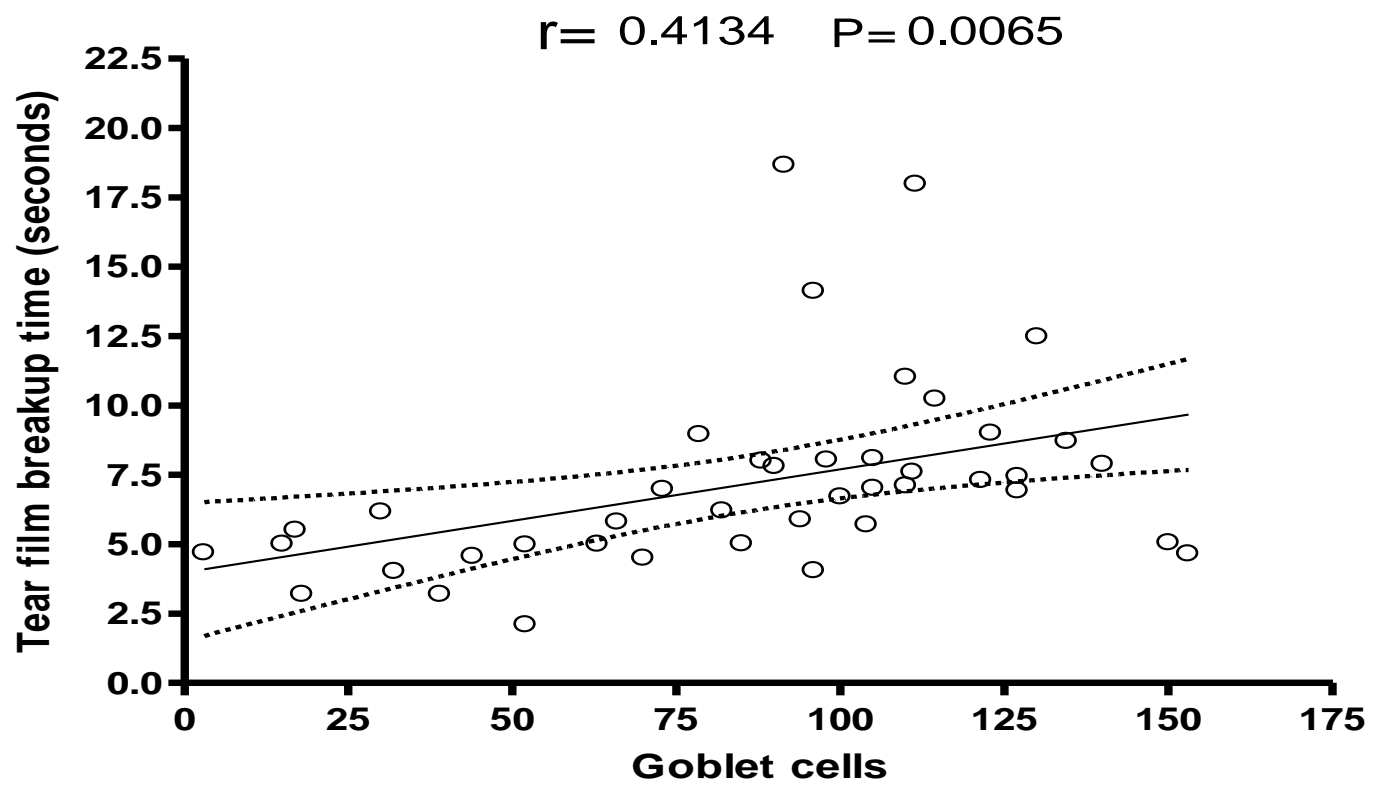

Figure 5. Linear regression curve indicating positive correlation between the tear film breakup time and the conjunctival goblet cells, considering the eyes of 10 healthy dogs and the 32 eyes of patients with mild, moderate, and severe keratoconjunctivitis sicca. The dotted line indicates the $95 \%$ confidence interval. 


\section{DISCUSSION}

In the present study, average TFBUT in healthy dogs (poodles and yorkshires) was 11.34 seconds (range 6.96 to 18.66 seconds). In beagles, such values varied from 19.67 to 21.53 seconds (Moore et al., 1987; Saito e Kotani, 2001). In healthy mesocephalic breeds, average TFBUT was 15.21 seconds (range 7.0 to 26.0 seconds) (Evans et al., 2012). In healthy brachycephalic breeds, values reported in different parts of the world varied from 10.77 (United States) to 13.66 seconds (Brazil) (Arnold et al., 2014; Kobashigawa et al., 2015). Although the study performed in healthy dogs has been conducted in a controlled environment, it is assumed that changes in the TFBUT values reported the literature may be related to differences with regard to temperature and humidity (Moore et al., 1987; Saito e Kotani, 2001; Arnold et al., 2014; Kobashigawa et al., 2015).

It is assumed that lacrimomimetics may reduce the signs of ocular discomfort related to blepharoconjunctivitis caused by the contact of hair and cilia, in dogs with eyelid abnormalities, and in those with ulcerative keratitis (Ribeiro, 2015). Differently from our hypothesis, except by the fact that TFBUT increased 3.8 seconds, following 1 minute of the instillation of $\mathrm{SH}$, both lacrimomimetics tested in the present study did not remain on the ocular surface of healthy dogs for not even 5 minutes. The same authors have observed similar results in an experiment conducted in healthy cats. It is believed that neuronal and chemical reflexes evoked by such agents may have stimulated tear secretion, helping these lubricants to be washed out from the ocular surface. Therefore, it is advised to test the effects of the same agents in higher concentrations, once dogs with acute blepharoconjunctivitis and ulcerative keratitis without KCS, usually present STT values above $15 \mathrm{~mm} /$ minutes (Ribeiro, 2015).

The present study was the first one to evaluate the TFBUT in different categories of dogs with KCS. Although values of such parameter decreased in accordance with the disease severity, statistical significance was only observed between the eyes graded as mild and severe. Considering the 32 eyes with KCS, TFBUT values (5.93 seconds, range 2.10 to 11.2 seconds) were similar to those reported in another research (6.2 to 7 seconds) conducted in dogs with KCS (Chen and Powell, 2015). In the study of Chen and Powell (2015), STT values ranged from 0 to $13 \mathrm{~mm} / \mathrm{minute}$, but authors did not separate the eyes with KCS in different categories. In diabetic dogs with qualitative KCS, TFBUT was 6.55 seconds, also similar with the ones observed in our study (Cullen et al., 2005).

In dogs with KCS, responsive eyes to cyclosporine and tacrolimus therapy take at least 30 days to achieve STT values similar to that of healthy individuals (Giuliano, 2013; Ribeiro, 2015). Thus, lacrimomimetics should be used to alleviate the signs of such disease at the beginning of treatment. Several studies evaluated the effects of SH in humans with KCS (Mengher et al., 1986; Hamano et al., 1996; Johnson et al., 2006).

Different authors have reported that one drop of $0.1 \% \mathrm{SH}$ was able to enhance TFBUT for up to 40 minutes (Mengher et al., 1986). Other authors have reported that the same agent, increased this parameter for up to 270 minutes (Hamano et al., 1996; Johnson et al., 2006). In vitro, CMC remained bound to human corneal epithelium cells for up to 2 hours (Garrett et al., 2007). However, studies in humans with KCS have shown that $0.5 \%$ CMC increased TFBUT by only 2 seconds, for no longer than 5 minutes (Simmons e Vehige, 2007). Another research conducted in humans with $\mathrm{KCS}$, did not considerate to assess the retention time of $0.5 \%$ $\mathrm{CMC}$ in minutes; authors have only reported that following several weeks of treatment, TFBUT values increased significantly in comparison to pre-treatment phase (Lee et al., 2011). Comparisons between $0.5 \% \mathrm{CMC}$ and $0.1 \% \mathrm{SH}$ showed that TFBUT increase in a similar fashion in humans with $\mathrm{KCS}$, under continuous treatment for 4 and 8 weeks (Lee et al., 2011). It was observed that the same agents increased TFBUT for up to 20 minutes in rabbits and rats with experimentally-induced KCS, without statistical significance between both drugs (Zheng et al., 2014).

In all categories of KCS evaluated herein, it was observed that both $0.1 \% \mathrm{SH}$ and $0.5 \% \mathrm{CMC}$ increased TFBUT, with the former being more efficient and lasting longer periods on the ocular surface. However, $\mathrm{SH}$ was able to remain on the 
ocular surface for only 30 minutes. Therefore, is reasonable to infer that such agents should be instilled every 30 minutes, and not every 4 to 6 hours, as recommended by the veterinary literature (Giuliano, 2013; Ribeiro, 2015; Williams and Mann 2013). A study carried out in dogs, has demonstrated that both application frequency and KCS symptoms are reduced, when the concentration of $\mathrm{SH}$ is increased and its molecule is modified (Williams and Mann, 2013). However, the same authors did not evaluate for how long this modified $\mathrm{SH}$ remained on the ocular surface of dogs with KCS (Williams and Mann, 2013). In humans with KCS, and in laboratory animals with experimentally-induced $\mathrm{KCS}$, concentrations of $1 \% \mathrm{CMC}$ and $0.3 \% \mathrm{SH}$ were significantly more efficient in enhancing the TFBUT values than solutions of the same drugs with concentrations at $0.5 \%$ and $0.1 \%$ (Simmons e Vehige, 2007; Zheng et al., 2014). However, Park et al. (2017) did not report differences when $0.1 \%, 0.15 \%$, and $0.3 \% \mathrm{SH}$ were compared in the eyes of humans with KCS. Another paper described that when both CMC and SH are compounded in the same solution, the TFBUT and GCD of rats improve substantially when compared with treatments where each agent were used separately (She et al., 2015).

The number of epithelium conjunctival cells used to quantify the GCD vary substantially among the studies conducted in dogs, and does not allow direct comparisons with our results (Moore et al., 1987; Cullen et al., 2005; Evans et al., 2012). In those studies, authors did not correlate GCD with TFBUT (Moore et al., 1987; Cullen et al., 2005; Evans et al., 2012). Cullen et al. (2005) quantified the GCD in healthy dogs, and in those with senile and diabetic cataract. Although authors have verified a significant reduction in TFBUT on diabetic dogs, GCD did not differ significantly between groups (Cullen et al., 2005). In our study, GCD was similar between healthy dogs and those with mild KCS. Despite the quantitative of these cells have decreased in patients with the moderate form of the disease, significant reduction was only observed in the eyes graded with severe KCS. However, positive correlation was noticed between TFBUT and GCD when all categories of eyes with KCS and the healthy eyes were grouped. STT is still considerate the gold standard test used to diagnose and grade the quantitative form of KCS in dogs (Giuliano, 2013). However, our results suggest that despite the absence of significance between GCD among the categories of healthy dogs and those with mild and moderate form of $\mathrm{KCS}$, that the tear film stability tends to reduce in a linear fashion as the disease progresses.

\section{CONCLUSION}

In this study, $0.15 \% \mathrm{SH}$ and $0.5 \% \mathrm{CMC}$ were able to increase TFBUT only in dogs with KCS. However, SH was significantly more efficient and remained for longer periods on the ocular surface. Correlations between GCD and TFBUT showed that the tear film stability tends to reduce in a linear fashion from the mild to severe form of KCS

\section{REFERENCES}

ARAUJO, D.M.L.; GALERA, P.D. Ocular lubrificants: what is the best choice? Cienc. Rural, v.46, p.2055-2063, 2016.

ARNOLD, T.S.; WITTENBURG, L.A.; POWELL, C.C. Effect of topical naltrexone $0.3 \%$ on corneal sensitivity and tear parameters in normal brachycephalic dogs. Vet. Ophthalmol., v.17, p.328-333, 2014.

CHEN, T.; POWELL, C.C. Effect of once daily topical $0.3 \%$ naltrexone on tear parameters and corneal sensitivity in dogs with uncontrolled keratoconjunctivitis sicca: a double-masked randomized placebo-controlled clinical trial. Vet. Ophthalmol., v.18, p.497-501, 2015.

CULLEN, C.L.; IHLE, S.L.; WEBB, A.A. et al. Keratoconjunctival effects of diabetes mellitus in dogs. Vet. Ophthalmol., v.8, p.215-224, 2005.

EVANS, P.M.; LYNCH, G.L.; LABELLE, P. Effects of oral administration of diphenhydramine on pupil diameter, intraocular pressure, tear production, tear film quality, conjunctival goblet cell density, and corneal sensitivity of clinically normal adult dogs. Am. J. Vet. Res., v.73, p.1983-1986, 2012.

GARRETT, Q.; SIMMONS, P.A.; XU, S. et al. Carboxymethylcellulose binds to human corneal epithelial cells and is a modulator of corneal epithelial wound healing. Invest. Ophthalmol. Vis. Sci., v.48, p.1559-1567, 2007. 
GIULIANO, E.A. Diseases and surgery of canine lacrimal secretory system. In: GELATT, K.N.; GILGER, B.C.; KERN, T.J. (Eds.). Veterinary ophthalmology. 5.ed. Iowa: WileyBlackwell, 2013. p.912-945.

HAMANO, T.; HORIMOTO, K.; LEE, M. et al. Sodium hyaluronate eye drops enhance tear film stability. Jpn. J. Ophthalmol., v.40, p.62-65, 1996.

HASEGAWA, T.; TANAKA, S.; SAWA, S. Clinical trial of a tear substitute containing $0.1 \%$ polyvinyl alcohol, $0.3 \%$ sodium hyaluronate, and $5 \%$ dodecahydrosqualene in 14 dogs with keratoconjunctivitis sicca: a pilot study. Vet. Ophthalmol., v.19, p.26, 2016.

JOHNSON, M.E.; MURPHY, P.J.; BOULTON, M. Effectiveness of sodium hyaluronate eye drops in the treatment of dry eye. Graefes Arch. Clin. Exp. Ophthalmol., v.244, p.109-112, 2006.

KOBASHIGAWA, K.K.; LIMA, T.B.; PADUA, I.R.M. Ophthalmic parameters in adult Shih Tzu dogs. Cienc. Rural, v.45, p.1280-1285, 2015.

LEE, J.H.; AHN, H.S., KIM, E.K. et al. Efficacy of Sodium hyaluronate and carboxymethylcellulose in treating mild to moderate dry eye disease. Cornea, v.30. p.175-179, 2011.

MENGHER, L.S.; PANDHER, K.S.; BRON, A.J. et al. Effect of sodium hyaluronate $(0.1 \%)$ on break-up time (NIBUT) in patients with dry eyes. Br. J. Ophthalmol. v.70, p.442-447, 1986.

MOORE, C.P.; WILSMAN, N.J.; NORDHEIM, E.V. et al. Density and distribution of canine conjunctival goblet cells. Invest. Ophthalmol. Vis. Sci., v.28, p.1925-1932, 1987.

PARK, Y.; SONG, J.S.; CHOI, C.Y. et al. A randomized multicenter study comparing $0.1 \%$, $0.15 \%$, and $0.3 \%$ sodium hyaluronate with $0.05 \%$ cyclosporine in the treatment of dry eye. J. Ocul. Pharmacol. Ther., 2017. Available in: $<$ http://online.liebertpub.com/doi/10.1089/jop.20 16.0086>. Accessed in: 04 Jan. 2017.
RIBEIRO, A.P. Oftalmologia. In: CRIVELLENTI, Z.; BORIN-CRIVELLENTI, S. (Eds.). Casos de rotina em medicina veterinária de pequenos animais, 2.ed. São Paulo: MedVet, 2015. p.683-722.

SAITO, A.; KOTANI, T. Estimation of lacrimal level and testing methods on normal beagles. Vet. Ophthalmol., v.4, p.7-11, 2001.

SHE, Y.; LI, J.; XIAO, B. et al. Ocular evaluation of a novel artificial tear in the prevention and treatment of dry eye in an animal model. J. Ocul. Pharmacol. Ther., v.31, p.525530. 2015.

SIMMONS, P.A.; VEHIGE, J.G. Clinical performance of a mid-viscosity artificial tear for dry eye treatment. Cornea, v.26, p.294-302, 2007.

WILLIAMS, D.L.; MANN, B.K. A crosslinked HA-based hydrogel ameliorates dry eye symptoms in dogs. Int. J. Biomater., 2013. Available in: <https://www.ncbi.nlm.nih.gov/pmc/articles/PM C3690250/>. Accessed in: 04 Jan. 2017.

YAO, K.; BAO, Y.; YE, J. et al. Efficacy of $1 \%$ carboxymethylcellulose sodium for treating dry eye after phacoemulsification: results from a multicenter, open-label, randomized, controlled study. BMC Ophthalmol., v.15, p.2-10, 2015.

ZHENG, X.; GOTO, T.; OHASHI, Y. Comparison of in vivo efficacy of different ocular lubricants in dry eye animal models. Invest. Ophthalmol. Vis. Sci. v.29, p.3454-3460, 2014. 